\title{
PERUBAHAN RUANG PADA TRADISI SEDEKAH LAUT DI KAMPUNG NELAYAN KARANGSARI KABUPATEN TUBAN
}

\author{
Helena Ramantika, Agung Murti Nugroho, dan Jenny Ernawati \\ Arsitektur Lingkungan Binaan, Universitas Brawijaya Malang \\ E-mail: helen.antika@yahoo.com; sasimurti@yahoo.co.id; \\ jny23ern@gmail.com
}

\begin{abstract}
Tradition "Sedekah Laut" often done by fishing communities is one of Indonesian culture. Karangsari village is one of the villages that still maintain this tradition. It becomes a form of gratitude in daily life, after their needs can be fulfilled well, the health of local residents guaranteed, and they got abundant catches. This study aimed to identify space changes in either micro, meso and macro scales of the tradition. The method used in this research is qualitative descriptive exploring the space and activities in it. The result showed that there was a change in the space in the tradition activity which occurs either in micro, meso and macro scales. The space chages followed the needs of the process in the tradition.
\end{abstract}

Tradisi sedekah laut yang sering dilakukan masyarakat nelayan merupakan salah satu kebudayaan Indonesia. Kampung Karangsari merupakan salah satu kampung yang masih mempertahankan tradisi sedekah laut. Kegiatan sedekah laut ini adalah suatu bentuk ungkapan syukur dalam kehidupan sehari-hari, dimana kebutuhan hidup dapat tercukupi dengan baik, kesehatan warga setempat terjamin, dan hasil laut dapat menghasilkan tangkapan yang melimpah. Penelitian ini bertujuan untuk mengidentifikasi perubahan ruang baik skala mikro, meso dan makro dalam tradisi sedekah laut. Metode yang digunakan dalam penelitian ini adalah deskriptif kualitatif, dengan mengeksplorasi ruang dan aktivitas yang terdapat di dalamnya. Hasil penelitian menunjukkan bahwa ada perubahan ruang ketika aktivitas tradisi sedekah laut terjadi baik skala mikro, meso dan makro. Perubahan ruang tersebut mengikuti kebutuhan proses kegiatan sedekah laut.

Keywords : culture, tradition, sedekah laut, change in space 


\section{Pendahuluan}

Tradisi merupakan suatu kebudayaan yang menjadi ciri lokalitas masyarakat Indonesia. Salah satunya kebudayaan Jawa yang sedikit banyak bermuatan nilai-nilai animisme dan dinamisme yang mendapat pengaruh Hindu-Budha, sesuai dengan kepercayaan dan keyakinan para pendahulu masyarakat Jawa. Kepercayaan animisme dan dinamisme ini sebenarnya telah dikenal oleh bangsa Indonesia sebelum masuknya pengaruh Hindu-Budha ke Indonesia. Setelah masuk dan berkembangnya pengaruh Hindu-Budha ke Indonesia mengakibatkan akulturasi, yaitu percampuran antara kedua kepercayaan. Pada setiap kebudayaan biasanya terdapat nilai-nilai tertentu yang mendominasi ide yang berkembang. Dominasi ide tertentu dalam masyarakat akan membentuk dan mempengaruhi aturan-aturan bertindak masyarakatnya (the rules of conduct) dan aturan-aturan bertingkah laku (the rules of behavior) yang kemudian secara bersama-sama membentuk pola kultural masyarakat. Berdasarkan hal tersebut, tradisi sedekah laut yang sering dilakukan masyarakat nelayan merupakan salah satu kebudayaan di Indonesia yang masih dipertahankan sampai sekarang. Tradisi sedekah laut yang salah satunya pada kampung nelayan Karangsari Kabupaten Tuban yang dilaksanakan setiap tahun. Hal inilah yang menyebabkan keunikan tersendiri, dimana dengan ruang yang terbatas tetapi masih bisa melaksanakan tradisi.

Ruang tidak dapat dipisahkan dari kehidupan manusia baik secara psikologi emosional (persepsi), maupun dimensional. Ruang terjadi secara visual dan non visual ( bau, sinar, angin, bayangan) dan keberadaannya lebih bertumpu pada rasa. Ruangan dalam suatu lingkungan binaan tidak hanya sekedar the sense of exposure, namun hendaknya menghadirkan suasana (atmosphere). Suasana dimunculkan oleh ruang dipengaruhi oleh ekspresi dari unsur pembentuk ruang, serta respon dari pengamat atau pemakai ruang (Hermanto, 2008: 26).

Tradisi sedekah laut yang ada pada kampung nelayan Karangsari memiliki makna tersendiri bagi masyarakat dan sesepuh dilokasi tersebut. Kebudayaan Jawa ini juga memiliki makna adanya toleransi dan rasa persaudaraan bagi masyarakat yang melaksanakannya. Arti dari tradisi sedekah laut itu adalah suatu bentuk persembahan kepada penguasa laut, yang mempunyai makna untuk menghindari dari musibah yang terjadi pada saat melaut dan sebagai perwujudan rasa bersyukur untuk hasil melaut. Sedekah laut dilakukan setelah hari lebaran atau pada waktu bulan tertentu yang telah ditentukan oleh sesepuh kampung. Pada tradisi ini sejumlah ritual digelar menurut tradisi 
dan adat di setiap masing-masing daerah atau pedukuhan. Menurut kampung nelayan Karangsari tradisi sedekah laut yang dilaksanakan adalah larungan laut, tetapi sebelum melakukan larung sesaji dilakukan dulu sesaji kepala sapi yang dipancang pada tonggak yang menghadap ke laut.

Dengan adanya tradisi sedekah laut di kampung nelayan Karangsari akan terjadi pergeseran ruang, yang pembentukan ruangnya beradaptasi dengan kegiatan tradisi tersebut. Perubahan teritori itu bisa berdasarkan perluasan ruang atas kebutuhan ruang akan interaksi masyarakat, sehingga perubahan teritori ruang membentuk suatu ruang-ruang bersama. Penelitian ini bertujuan untuk mengidentifikasi perubahan ruang yang terjadi akibat tradisi sedekah laut baik skala mikro,meso dan makro, sehingga dapat diketahui perubahan ruang yang terbentuk.

\section{Landasan Teori}

Sedekah laut merupakan sebuah tradisi yang dilaksanakan oleh masyarakat pesisir atau nelayan. Dalam sedekah laut ini menghadirkan kembali suatu proses atau peristiwa yang pernah dilakukan dahulu oleh leluhur. Maka usaha serupa pun akan terjadi lagi, karena hadirnya prosesi sedekah laut di masyarakat nelayan telah lama dan menjadi bagian didalam kehidupannya. Simbol-simbol yang ada didalam prosesi ini dapat berubah namun fungsinya akan tetap sama. Tata cara tradisi tiap daerah juga berbeda-beda sesuai keyakinan yang dipercaya oleh para nelayan sekitar. Tetapi pada dasarnya tradisi ini mempunyai makna yang sama, yaitu persembahan kepada Sang Penguasa yang diperuntukkan lewat penguasa laut. Masyarakat nelayan sendiri percaya akan sedekah laut, jika tidak melakukan sedekah laut bisa terjadi musibah pada perahu dan diri sendiri, serta hasil laut tidak bisa didapat secara maksimal.

Ragam dan makna sesaji Tradisi sedekah laut adalah sebagai berikut:

1. Kepala Sapi, sebagai persembahan kepada laut yang bermakna nelayan harus guyub (rukun) dan selalu mempererat tali silaturahmi antar nelayan.

2. Pisang sanggan, sebagai lambang bahwa raja atau ratu adalah yang tertinggi.

3. Pisang raja pulut, sebagai lambang pengikut, supaya tetep, lengket, kelet, sehingga hubungan antara raja dengan rakyat itu tetap abadi dan melekat.

4. Jenang palang (merah putih) dengan palang, sebagai lambang supaya masyarakat Ngentak dalam mencari nafkah tidak ada yang menghalang-halangi, 
5. Jenang merah putih, sebagai lambang ibu yang melahirkan manusia,

6. Jenang hitam, sebagai lambang persembahan kepada saudara atau kakang kawah adi ari-ari

7. Nasi ameng, sebagai lambang permohonan keselamatan dari Yang Maha Agung,

8. Nasi rasulan/udhuk, sebagai lambang junjungan Nabi Muhammad SAW,

9. Ayam ingkung, sebagai lambang junjungan Nabi Besar Muhammad SAW.

10. Air tawar, sebagai lambang keselamatan (Dion, 2013: 2).

Dengan adanya tradisi sedekah laut akan membentuk ruang-ruang baru dimana tradisi tersebut dilaksanakan. Ada beberapa pendapat yang mencoba untuk mendefinisikan ruang:

1. Ruang adalah sebuah, bahkan sejumlah tempat, sebuah lahan yang dinamis dengan benda-benda yang berhubungan langsung dan kualitatik pada penggunanya.

2. Ruang dalam kaitannya dengan tingkah laku yakni ruang tersebut adalah tempat berinteraksi antar manusia yang beraktivitas dan bertingkah laku

3. Ruang tercipta dengan bahan dan struktur agar terdapat rongga untuk kegiatan manusia

4. Ruang dalam kaitannya dengan psikologi, yakni ruang berkaitan dengan persepsi dari egosentris pelakunya, bahwa ruang akan tergantung pada keragaman pengalamannya, dimana tempat yang sama mungkin saja ditanggapi berbeda-beda antara masing-masing orang (Agustrapaja, 2011: 82).

Perubahan ruang akibat adanya adaptasi lingkungan sekitar dapat mempengaruhi ruang personal individu atau kelompok sehingga tingkat privasi akan dapat beradaptasi secara fleksibel (Putri, 2012: 66). Ruang pribadi seolah-olah merupakan sebuah balon atau tabung yang menyelubungi kita, membatasi jarak dengan orang lain, dan tabung itu membesar atau mengecil bergantung dengan siapa kita sedang berhadapan (Laurens, 2004: 108).

Perubahan ruang adalah perpindahan lokasi kepadatan dan faktor pengubah yang menyebabkan terjadinya perubahan fungsi ruang tersebut dalam suatu kepadatan kegiatan. Hubungan antar ruang mikro, meso dan 
makro dapat menunjukkan hierarki ruang dari tiap-tiap ruang (Yuwanti, 2012: 207). Dalam penggunaan ruang dalam skala mikro, meso dan makro akan menunjukkan suatu hirarki tertentu baik dari hirarki privat-publik. Dalam pengamatan terhadap aspek fisik ruang akan dapat diperoleh pemahaman utuh apabila pengamatan tidak secara parsial karena keterkaitan hirarki dalam penggunaan ruang (Ayuninggar, 2013: 35).

Dalam mengidentifikasi tatanan ruang permukiman, mengungkapkan dua elemen penting yaitu yaitu skala ruang dan struktur ruang. Skala ruang menguraikan hubungan antar ruang, yang terbagi dalam ruang mikro, meso dan makro. Analisa mikro menunjukkan pola penggunaan ruang dalam skala kecil, seperti rumah, gubug, serta fasilitas-fasilitas tertentu yang memiliki bagian-bagian yang berfungsi dalam setiap aktivitas tradisi. Analisa skala meso dilakukan untuk mengetahui hubungan antar ruang dalam batasan tertentu, misalnya ruang yang digunakan bersama-sama dalam satu permukiman. Analisa skala makro, dilaksanakan untuk menilai hubungan antar ruang secara menyeluruh yang dikaitkan dengan fungsi dan aktivitas individu (Tallo, 2013: 21)

\section{Metode Penelitian}

Penelitian ini menggunakan jenis metode penelitian deskriptif kualitatif, dikarenakan penelitian ini ada kaitannya dengan ruang dan aktivitas yang terdapat di dalamnya maka digunakan pendekatan environment behaviour study. Metode ini bertujuan untuk mencari informasi bagaimana suatu perubahan ruang terhadap tradisi sedekah laut yang ada pada Kampung Nelayan, sehingga dapat dihasilkan penilaian secara subjektif berdasarkan objek yang ada dalam penelitian yang kemudian didapatkan kesimpulan data.

Pengumpulan data dilakukan dengan cara dokumentasi dalam foto dan wawancara kepada orang-orang yang mengetahui secara jelas tentang tradisi yang akan mempengaruhi perubahan ruang.

\section{Gambaran Umum Lokasi Studi}

Tuban merupakan kota tua yang letaknya berada di pantai Utara Jawa. Tuban juga merupakan salah satu kota pelabuhan utama pada masa Kerajaan Majapahit. Pada masa penyebaran agama Islam, Tuban menjadi pintu dan merupakan salah satu pusat penyebaran agama Islam di Jawa, khususnya Jawa Timur. Hal ini terbukti dengan adanya makam Sunan Bonang yang berada pada sebelah Masjid Agung. Sekarang ini Tuban lebih terkenal dengan julukan Kota Wali. 
Salah satu daerah pesisir yang ada di Tuban adalah Kelurahan Karangsari, dimana kelurahan ini berada pada sepanjang pantai dan jalur pantura. Laut Jawa yang terletak di sepanjang Utara Kelurahan Karangsari menyebabkan kawasan ini sangat potensial dalam bidang perikanan dan kelautan. Laut merupakan sumber kehidupan bagi warga Karangsari sehingga kawasan ini perlu dilengkapi dengan sarana pengolahan hasil laut yang layak. Sarana dan prasarana pengolahan hasil laut yang layak dapat meningkatkan penghasilan para nelayan. Terlihat pada kondisi eksisting Kelurahan Karangsari bahwa kawasan ini sudah memanfaatkan lahan disekitar rumahnya untuk mengolah hasil tangkapan laut, tetapi kurang tertata sehingga terkesan kumuh.

Kelurahan Karangsari berbentuk memanjang di sepanjang pantai Laut Jawa. Dari segi geografis lokasi ini sangat cocok untuk mengembangkan sektor pariwisatanya. Dari segi adat istiadat, kampung ini memiliki kegiatan rutin tiap tahunnya dengan sedekah laut sehingga cocok untuk mengembangkan wisata adat atau religi. Proses ritual seperti tradisi sedekah laut ini dipengaruhi konsep Hindu yang menganggap raja adalah dewa atau yang dikenal sebagai konsep Dewa-Raja. Konsep ini menganggap raja-raja Jawa sebagai titisan Dewa atau bahkan dewa itu sendiri.

Masyarakat Kelurahan Karangsari hampir seluruhnya memeluk agama Islam, dengan kehidupan kesehariannya yang masih cukup menempel karakter budaya kejawen yang juga terdapat di dalam agama Islam. Banyak tradisi-tradisi yang dilakukan warga Kelurahan Karangsari berdasarkan dengan kepercayaan Jawa, diantaranya yaitu tradisi sedekah laut, ruwah, dan sebagainya. Di dalam pelaksanaan tradisi tersebut dilakukan untuk ucap syukur kepada Tuhan atas kenikmatan yang telah tercapai dalam pencarian nafkah.

\section{Tradisi Sedekah Laut}

Tradisi sedekah laut merupakan salah satu kegiatan ritual yang terus menerus dilakukan oleh warga Kampung Karangsari. Kegiatan sedekah laut ini adalah suatu bentuk ungkapan syukur dalam kehidupan sehari-hari, dimana kebutuhan hidup dapat tercukupi dengan baik, kesehatan dari warga setempat terjamin, dan hasil laut dapat menghasilkan tangkapan yang melimpah. Tradisi ini juga berdasarkan pada kepercayaan adanya Dewi Lanjar, dimana Dewi ini merupakan wujud dari penghuni Laut Utara. Oleh karenanya, pada acara ritual ini warga setempat juga mewujudkan Dewi Lanjar dalam acara arak-arakan. 

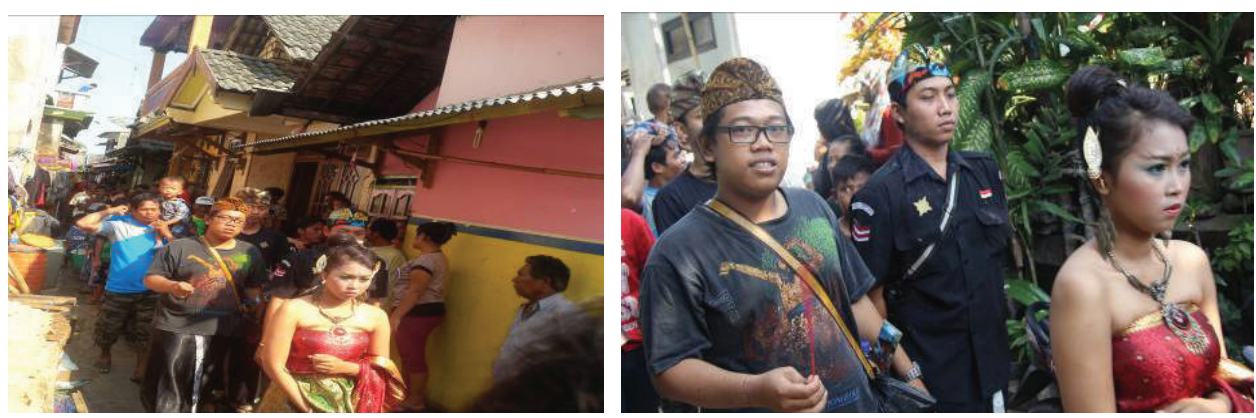

Gambar 1. Perwujudan dari Dewi Lanjar

Dalam tradisi sedekah laut juga harus ada sesajen sebagai bentuk rasa terima kasih karena hasil melaut. Sesajen yang wajib ada adalah Bekakak dan Kepala Sapi. Bekakak sendiri merupakan perahu kecil sebagai simbol dari perahu-perahu nelayan, yang didalamnya terdapat sesajen dan simbol dari Raja Ratu Pantai utara, yang diwujudkan dalam sepasang boneka Barbie. Bekakak akan dilarung sebagai simbol persembahan dari para nelayan agar laut memberikan hasil ikan yang melimpah.
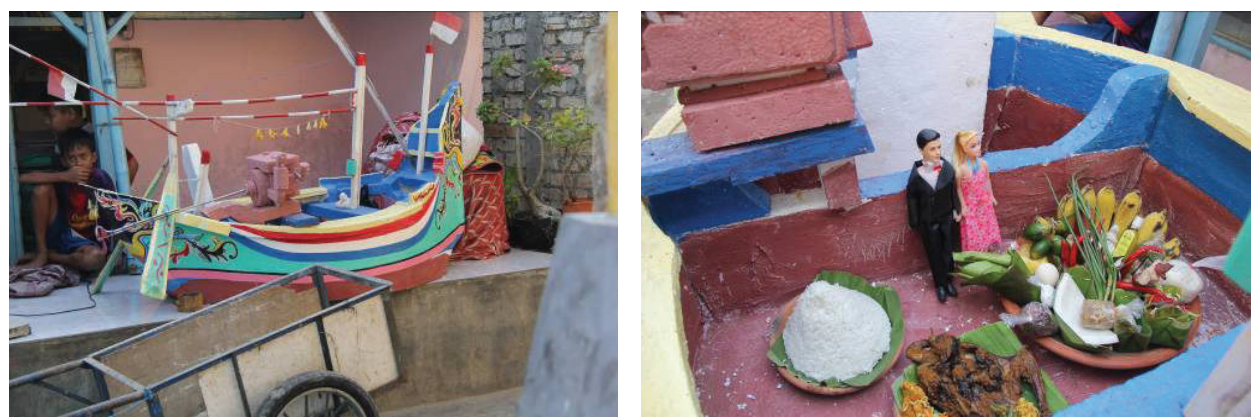

Gambar 2. Sesaji Bekakak

Untuk kepala sapi juga wajib ada dalam kegiatan tradisi sedekah laut ini, karena merupakan persembahan agar nelayan selalu diberi keselamatan dalam melaut. Kepala sapi ini diberi doa dulu yang kemudian akan dipancung di laut pada batang pohon kelapa yang sudah ditancapkan. 

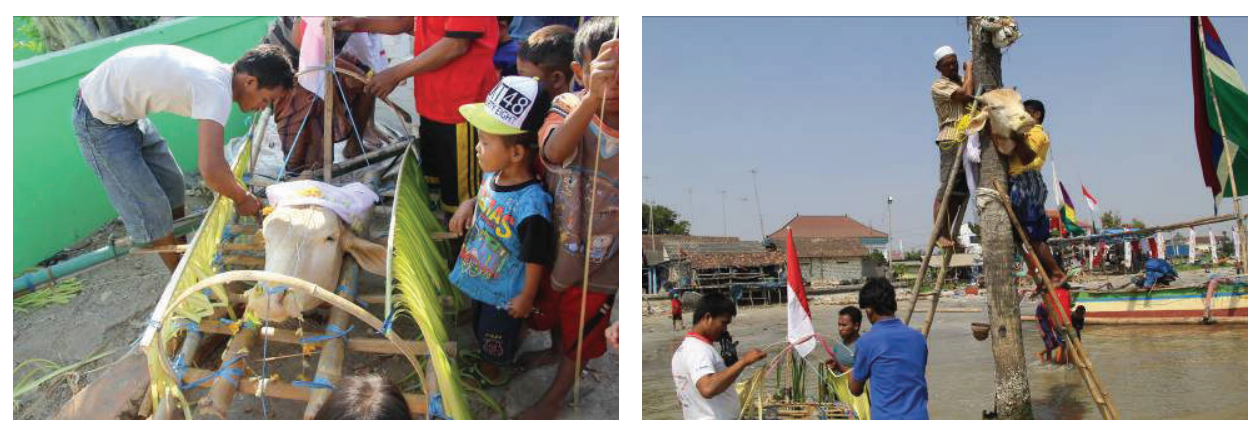

Gambar 3. Sesaji Kepala Sapi

Pada tahun 2014 kegiatan sedekah laut dilaksanakan pada tanggal 1 Oktober. Aktivitas pada kegiatan sedekah laut dibagi menjadi dua tahapan yaitu tahap persiapan dan tahap pelaksanaan atau acara sedekah laut itu sendiri. Tahap persiapan sedekah laut dilakukan pada tanggal 30 September 2014. Pada tahap persiapan acara antara lain untuk menyiapkan sesaji, arakarakan, masak-memasak dan dekorasi lainnya. Pelaksanaannya dimulai pada pagi hari dengan pemotongan kepala Sapi yang dilaksanakan di sekitar rumah Pak Waras. Lalu kemudian dilakukan arak-arakan mengelilingi Kampung Karangsari sampai ke acara inti yaitu sedekah laut dengan melarungkan sesaji. Berikut adalah peta kegiatan selama acara sedekah laut. Pelaku adalah Paguyuban Nelayan Bahari Karangsari Tuban, para juragan perahu dan seluruh warga Karangsari yang turut menyaksikan acara tersebut.

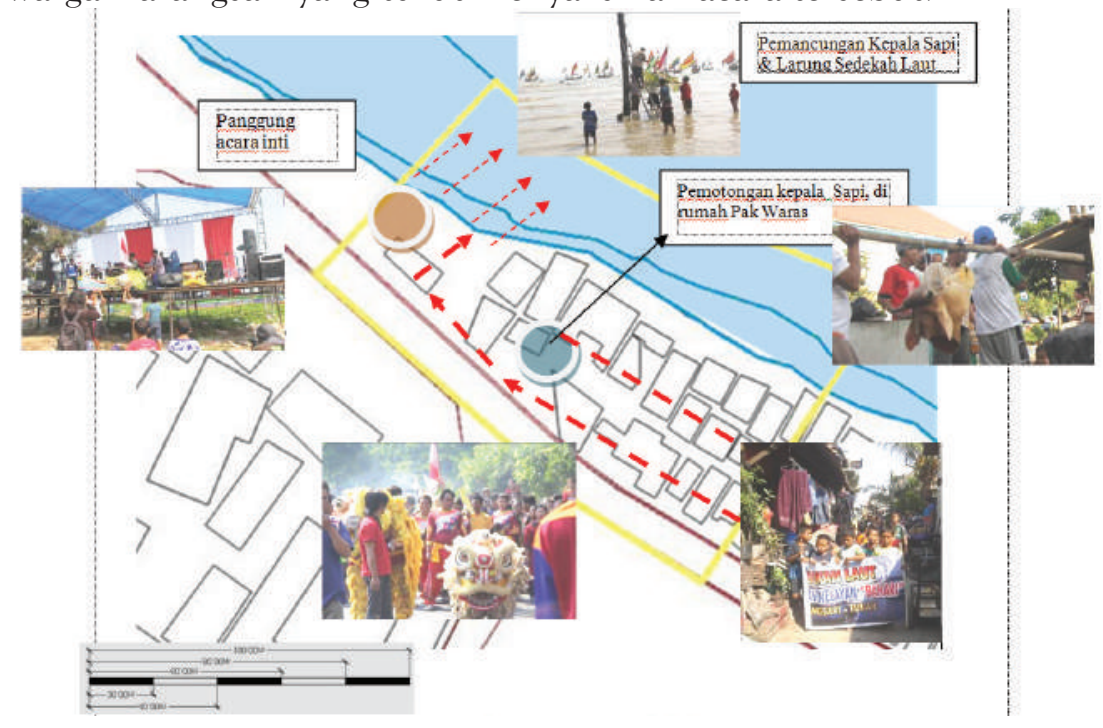

Gambar 4. Alur Kegiatan Sedekah Laut 


\section{Perubahan Ruang yang Terjadi di Kampung Karangsari akibat Sedekah Laut}

Aktivitas yang dilakukan masyarakat akan mempengaruhi bentukan ruang yang tercipta baik dari sisi sosial antar individu dari masyarakat nelayan tersebut. Pola pemukiman di Kampung Karangsari berbentuk linear memanjang mengikuti garis pantai. Rumah-rumah di Karangsari berkumpul dan memanjang. Masing-masing rumah memiliki jarak yang berdekatan. Dengan adanya tradisi sedekah laut akhirnya terbentuk ruang-ruang secara sosial yang digunakan bersama-sama oleh masyarakat Karangasari.

Berikut adalah sampel-sampel yang didapat berdasarkan pengambilan sampel dengan cara purposive sampling. Purposive sampling ini bertujuan untuk mewakili kriteria yang dicari untuk mendapatkan hasil perubahan ruang pada sedekah laut.

1. Sampel rumah dari Pak Mukharyono yang berprofesi sebagai Juragan Perahu merupakan salah satu rumah yang digunakan untuk persiapan sampai acara sedekah laut.

2. Sampel rumah dari Pak Waras yang berprofesi sebagai Juragan Perahu sekaligus ketua panitia dari acara sedekah laut yang juga merupakan salah satu rumah yang digunakan untuk persiapan sampai acara sedekah laut berlangsung.

3. Sampel Kampung Karangsari itu sendiri berdasarkan ruang makro, meso dan mikro yang terjadi pada saat persiapan sampai acara sedekah laut berlangsung.

Berikut adalah peta Kampung Karangsari dan sampel-sampel yang telah ditunjuk.

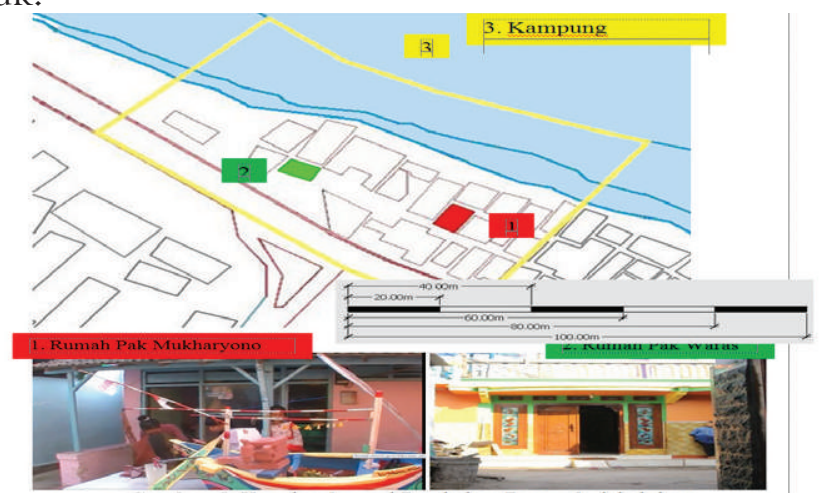

Gambar 5. Keyplan Sampel Perubahan Ruang Sedekah laut di Kampung Karangsari 
a. Rumah Pak Mukharyono
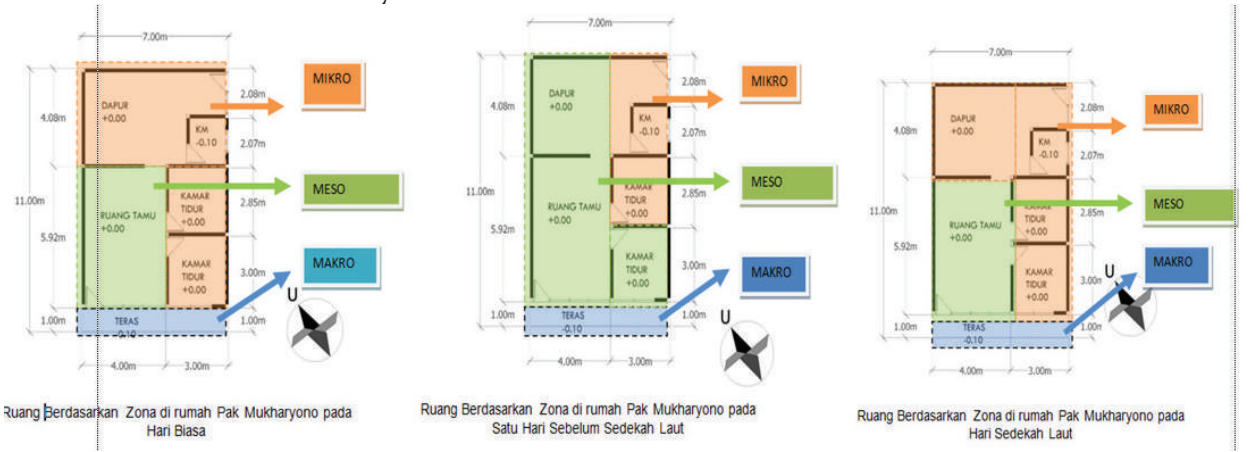

Gambar 6. Perubahan ruang pada Rumah Pak Mukharyono

Tabel 1. Perubahan ruang pada Rumah Pak Mukharyono

\begin{tabular}{|l|l|l|l|}
\hline Hari & Mikro & Meso & Makro \\
\hline Biasa & $\begin{array}{l}\text { 2 Kamar Tidur } \\
1 \text { Kamar Mandi } \\
1 \text { Dapur }\end{array}$ & 1 Ruang Tamu & 1 Teras \\
\hline H-1 Acara & $\begin{array}{l}1 \text { Kamar Tidur } \\
1 \text { Kamar Mandi }\end{array}$ & $\begin{array}{l}1 \text { Ruang Tamu } \\
1 \text { Kamar Tidur } \\
1 \text { Dapur }\end{array}$ & 1 Teras \\
\hline Saat Acara & $\begin{array}{l}\text { 2 Kamar Tidur } \\
1 \text { Kamar Mandi } \\
\text { Dapur }\end{array}$ & 1 Ruang Tamu & 1 Teras \\
\hline
\end{tabular}

b. Rumah Pak Waras
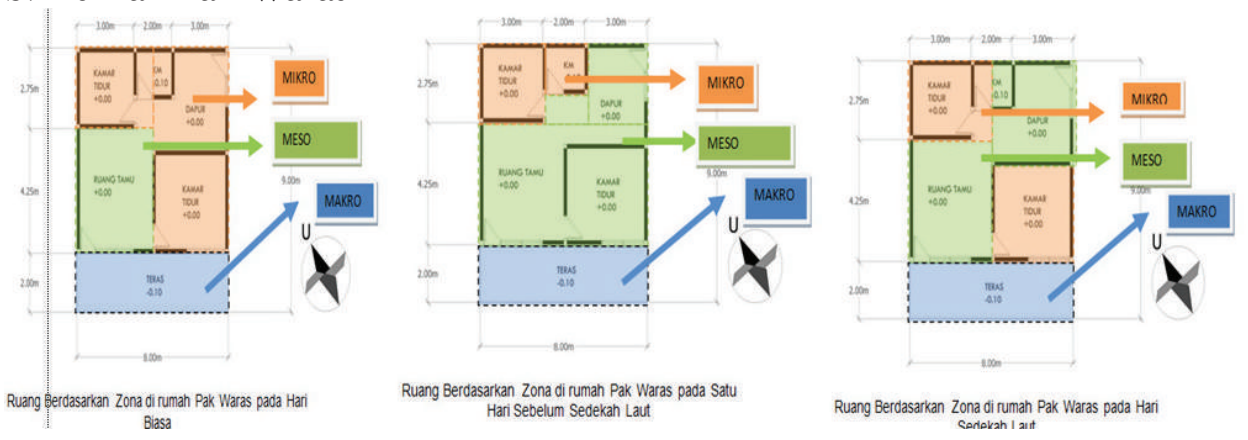

Gambar 7. Perubahan ruang pada Rumah Pak Waras 
Tabel 2. Perubahan ruang pada Rumah Pak Waras

\begin{tabular}{|l|l|l|l|}
\hline Hari & Mikro & Makro & Meso \\
\hline Biasa & $\begin{array}{l}1 \text { Kamar Tidur Depan } \\
1 \text { Kamar Tidur } \\
\text { Belakang } \\
1 \text { Kamar Mandi } \\
1 \text { Dapur }\end{array}$ & 1 Teras \\
\hline H-1 Acara & $\begin{array}{l}1 \text { Kamar Tidur } \\
\text { Belakang } \\
1 \text { Kamar Mandi }\end{array}$ & $\begin{array}{l}1 \text { Ruang Tamu } \\
1 \text { Kamar Tidur } \\
\text { Depan } \\
1 \text { Dapur }\end{array}$ & 1 Teras \\
\hline Saat Acara & $\begin{array}{l}\text { 2 Kamar Tidur } \\
1 \text { Kamar Mandi }\end{array}$ & $\begin{array}{l}1 \text { Ruang Tamu } \\
1 \text { Dapur }\end{array}$ & 1 Teras \\
\hline
\end{tabular}

c. Kampung Karangsari

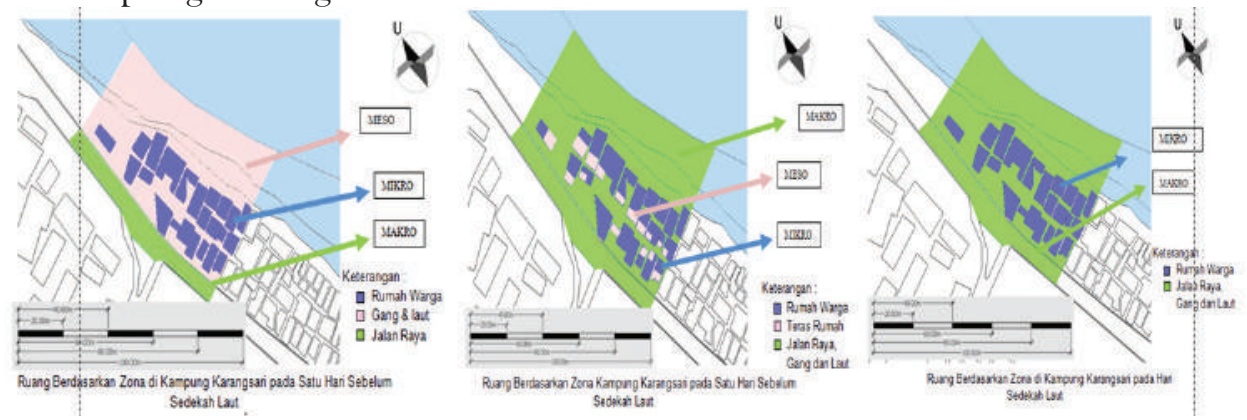

Gambar 8. Perubahan ruang pada Kampung Karangsari

Tabel 3. Perubahan ruang pada Kampung Karangsari

\begin{tabular}{|c|c|c|c|}
\hline Hari & Mikro & Meso & Makro \\
\hline Biasa & $\begin{array}{l}\text { Unit Rumah Tinggal } \\
\text { Juragan Perahu }\end{array}$ & $\begin{array}{l}\text { Jalan dan gang- } \\
\text { gang kecil/lorong } \\
\text { di Kampung } \\
\text { Karangsari dan Laut }\end{array}$ & $\begin{array}{l}\text { Jalan Raya dan } \\
\text { Fasilitas Umum }\end{array}$ \\
\hline
\end{tabular}




\begin{tabular}{|c|l|l|l|}
\hline H-1 Acara & $\begin{array}{l}\text { Sebagian besar ruangan } \\
\text { di Unit Rumah Tinggal } \\
\text { Juragan Perahu }\end{array}$ & $\begin{array}{l}\text { Ruang pada } \\
\text { Rumah Tinggal } \\
\text { Juragan Perahu } \\
\text { yang digunakan } \\
\text { untuk melakukan } \\
\text { persiapan acara }\end{array}$ & $\begin{array}{l}\text { Jalan dan gang- } \\
\text { gang kecil/lorong } \\
\text { di Kampung } \\
\text { Karangsari, Laut, } \\
\text { Jalan Raya, dan } \\
\text { Fasilitas Umum }\end{array}$ \\
\hline Saat Acara & $\begin{array}{l}\text { Unit Rumah Tinggal } \\
\text { Juragan Perahu }\end{array}$ & - & $\begin{array}{l}\text { Jalan dan gang- } \\
\text { gang kecil/lorong } \\
\text { di Kampung } \\
\text { Karangsari, Laut, } \\
\text { Jalan Raya, dan } \\
\text { Fasilitas Umum }\end{array}$ \\
\hline
\end{tabular}

\section{Simpulan}

Kampung Karangsari merupakan salah satu kampung yang masih mempertahankan tradisi. Tradisi tersebut adalah tradisi sedekah laut, yaitu persembahan sesaji untuk laut yang telah memberi hasil ikan melimpah yang dilaksanakan tiap tahun sekali. Dengan adanya aktivitas tradisi sedekah laut maka terjadi perubahan ruang baik secara mikro, meso dan makro. Perubahan ruang tersebut mengikuti kebutuhan dari proses kegiatan sedekah laut. Perubahan ruang tersebut menjadikan suatu ruang menjadi sangat berkualitas yang digunakan dalam tradisi sedekah laut.

\section{Daftar Pustaka}

Agustrapaja, Hammam Rofiqi. 2011. Ruang Budaya Pada Upacara Karo Di Desa Ngadas, Tengger. Prosiding Seminar Nasional (The Local Tripod). Malang: Jurusan Arsitektur Fakultas Teknik Universitas Brawijaya.

Ayuninggar D.P., Antariksa, Wardhani D.K. 2013. Sosial Budaya Pembentuk Permukiman Masyarakat Tengger Desa Wonokitri Kabupaten Pasuruan. 5:(1) 1-11 (http://tatakota.ub.ac.id/index.php/tatakota/article/view/155/152, diakses tanggal 20 Juni 2014).

Fajar,Dion.2013.http://news.detik.com/read/2013/10/16/142417/2387036/ 475/3/nelayan-tuban-larung-sesaji-dan-pancang-kepala-kerbau diakses pada tanggal 02 Juni 2014. 
Hermanto, Heri. 2008. Faktor-Faktor Yang Berpengaruh Terhadap Perubahan Fungsi Ruang Di Serambi Pasar Induk Wonosobo. Tesis Program Pasca Sarjana Universitas Diponegoro, Semarang.

Laurens, Joyce Marcella. 2004. Arsitektur dan Perilaku Manusia. Jakarta: PT Grasindo.

Putri, Rr., Pangarsa, Galih Widjil., Ernawati, Jenny. 2012. Pendekatan Teritori Pada Fleksibilitas Ruang dalam Tradisi Sinoman Dan Biyada Di Dusun Karang Ampel Malang. Dimensi (Journal of Architecture and Built Environment) Vol. 39, No. 2 : 65-76.

Tallo, Amandus Jong. 2013. Struktur Ruang Permukiman Suku Atoni Berbasis Budaya, Studi Kasus: Kampung Adat Tamkesi, Kabupaten Timor Tengah Utara. Jurnal Tesa Arsitektur.

Yuwanti, Sri. 2012. Perubahan Struktur Ruang Pusat Kota Akibat Kegiatan Ekonomi Rakyat. Semarang : CV Tunggal Sakti. 